Biochem. Lett., Vol. 7, PP. 1-21 (2012)

\title{
HUMORAL IMMUNE RESPONSE TO ACETAMIPRID EXPOSURE AND ITS MODULATION BY SUPPLEMENTATION WITH \\ VITAMIN C IN RATS
}

\author{
Nagi A. Ibrahim ${ }^{1}$, Ahmed M. GabAllah ${ }^{2}$ and \\ Hanim S. Hendawy ${ }^{1}$ \\ 1- Zoology Department, Faculty of Sciences, \\ Zagazig University \\ 2- Department of Clinical Pathology, Faculty of \\ Medicine , , Zagazig University
}

\begin{abstract}
Acetamiprid (AP) is a fairly new neonicotinoid insecticide. Its indiscriminate use both in agriculture and domestic areas against wide range of pests such as aphids and whiteflies is causing toxicity to man and animals. In recent years the effects of insecticides on immune response have received more attention. The present study was designed to evaluate the toxic effect of repeated oral (by gavage) administration of $A P$ over six weeks on humoral immune response. Forty eight adult male Sprague Dawley rats were divided into four groups (12 animals each). Animals of the $1^{\text {st }}$ group were untreated and served as control, rats of the $2^{\text {nd }}$ group were orally given $1 / 10$ LD50 (83.18 $\mathrm{mg} / \mathrm{kg} \mathrm{b}$. wt.), animals of the $3^{\text {rd }}$ group were administered orally vitamin C alone at a dose level of $200 \mathrm{mg} / \mathrm{kg}$ b.wt, every other day for six weeks, rats of the $4^{\text {th }}$ group were given AP similar to those of the $2^{\text {nd }}$ group then administered orally with vitamin C similar to those of the $3^{\text {rd }}$ group 30 minutes after each $A P$ administration. At day one after the end of experiment, eight rats were picked up randomly from each group, blood samples were collected from each animal under slight ether anaethesia through heart puncture into plain vaccutainer tubes and sera were separated. Data obtained revealed that oral AP administration into rats induced a non significant increase in IgM level ; significant decrease and
\end{abstract}


Humoral Immun Response To Acetamiprid

increase in IgG and IL - 6 levels respectively as compared to the control values. Supplementation with vitamin $C$ potentiated significantly the effect of AP on IgM, WBCs count, monocytes and lymphocytes percentage, and reduced significantly its effects on IgG and IL-6. These data indicate that $A P$ is capable of inducing changes in humoral immunity that could be selectively modulated by supplementation with vitamin $C$.

\section{INTRODUCTION}

Insecticides are the only toxic chemicals deliberately released into the environment in large amounts. Their potential to cause adverse effects to human and wildlife populations has been the subject of intense study and has lead to the development of increasingly stringent and encompassing regulations for the risk assessment of noval formulation and to control the use of existing compounds $(\mathbf{1 , 2 , 3 , 4 , 5 , 6 , 7 )}$.

Neonicotinoid, the major new class of insecticides, have begun replacing organophosphorous, organochlorines and pyrethroid compounds for crop protection against piercing-sucking insects and for animal health care ${ }^{(\mathbf{8 , 9})}$. Toxicity of this class of insecticides is considered to be due to their action at the nicotinic acetylcholine receptors of insects and mammals ${ }^{\mathbf{1 0}}$.

Acetamiprid (AP), a member of the neonicotinoid insecticide family, is a fairly new insecticide that provides selective outstanding control against sucking pests such as aphids and whiteflies on leafy vegetables and have been widely adopted in many commercial markets niches throughout the world ${ }^{(11)}$. Indescriminate use of AP to manage insects by farmers causing its entry into food chain, which, in turn in instigating residue - related toxicity to human beings and animals ${ }^{(\mathbf{1 2}, 13)}$.

The immune system contains three components : Humoral immunity, cell-mediated immunity, and nonspecific immunity. These components are usually described as isolated functional units, but they are, in fact, parallel systems that interact and regulated the responses 
Nagi A. Ibrahim. et al..

of each. Alterations of a specific immune function may result in corresponding modulation of other immune functions ${ }^{(2)}$.

The immune system has been shown to be an important target organ of toxicity following exposure to chemicals ${ }^{(14,15)}$. Although there is a large body of literature addressing immune responses during exposure to a wide variety of insecticides including carbamates ${ }^{(16)}$, organochlorines (17), pyrethroides (18), organophosphorous compounds ${ }^{19}$, and more recently neonicotinoids ${ }^{(20,21)}$, there have been few studies of AP' $s$ immune system effects. AP has been found to have adverse action on humoral immunity as was determined by antibody response against sheep red blood cells (RBCs) using micro Haemagglutination (HA) test following its oral administration to female Wister rats ${ }^{\mathbf{1 2}}$.

Several scavenging agents and antagonists are established to reduce pesticides toxicity ${ }^{(22,23)}$, however, some of them are burned with undesirable side effects . Vitamin C (L-ascorbic acid) is a well known antioxidant, which functions as an electron donor to protect the body from radical and pollutants ${ }^{(24,25)}$.

The objective of this study is to further examine (asses) humoral immune response to repeated post oral (po) administration of $\mathrm{AP}$ and the possible ameliorative effect of vitamin $\mathrm{C}$.

\section{MATERIAL AND METHODS}

Male Sprague - dawley rats weighing 150-200 g were used in this study. They were purchased from the animal house of the National Research Center, Dokki, Giza, Egypt. Rats were housed under standard laboratory conditions. They had free access to a standard food and provided with tap water ad libitum. All animals were acclimatized to these conditions for 10 days before being used.

Acetamiprid 20\% SP was purchased from Shoura Co. , for chemicals, Kilo 28 Cairo - Alex desert Road, Egypt. Vitamin C was purchased as ampoules under a trade name Cevarol from Memphis Co. for pharm \& Chemical Ind. Cairo, Egypt. 
The acute po $\mathrm{LD}_{50}$ of acetamiprid for male Sprague - dawley rats was determined according to the method of Reed et $a^{(., 26)}$ and was found to be $831.8 \mathrm{mg} / \mathrm{kg}$ b.wt.

Rats were randomly allocated into four groups (12 rats each). Animals of the $1^{\text {st }}$ group were not treated and served as controls. Rats of the ${ }^{2 n d}$ group were given po by gavage acetamiprid at a dose level of $1 / 10 \mathrm{LD}_{50}$ every other day for six weeks. Animals of the $3^{\text {rd }}$ group were administered po every other day with vitamin $\mathrm{C}$ at a dose level of $200 \mathrm{mg} / \mathrm{kg} \mathrm{b} . \mathrm{wt}^{(.27,28)}$ for six weeks. Rats of the $4^{\text {th }}$ group were given a similar dose level of vitamin C 30 minutes after each acetamiprid administration.

At the end of the treatment periods, eight rats from each group were deprived of food for overnight these rats were slightly anaesthetized with ether and blood samples were collected through heart puncture into plain vaccutainer tubes and centrifuged at $1500 \mathrm{x} \mathrm{g}$ for 15 minutes. Sera samples were separated in eppendorfs and kept at $-80^{\circ} \mathrm{c}$ till the immunological analysis were started. Other blood samples were collected into vaccutainer tubes containing EDTA for white blood cells (WBCs) count.

Determination of serum immunoglobutins IgG and IgM concentrations of control and treated rats were carried out by immunonephrometry on the BN ProSpec System manufactured by Dade Behring GmbH, Marburg, Germany. Following the method described by Thomas ${ }^{29}$. Measurement of serum IL-6 concentrations of control and treated rats was carried out using AviBion Enzyme Linked Immunosorbent Assay (ELISA) kits (Orgenium Laboratories, Helsinki, Finland), according to the manufacture's instructions. Total WBCs count, monocytes, and lymphocytes percentages were measured following the methods described by Harris et al ${ }^{(, 30)}$ using the automated Bayer ADVIA 120 Hematology System manufactured by Bayer Health care, Diagnostics Division, Tarrytown, NY. USA.

Data of each group were statistically analyzed using student " $t$ " test according to Hill, ${ }^{31}$ after one way analysis of variance (ANOVA) 
Nagi A. Ibrahim. et al..

when multiple comparison was made according to Kirkwood $^{32}$. Results were considered statistically significant at $\mathrm{P}<0.05$

\section{RESULTS}

Data presented in table (1) and illustrated graphically in figures 1,2 and 3 indicate that subchronic po administration of acetamiprid to male Sprague Dawley rats at the dose level of 1/10 $\mathrm{LD}_{50}(83.18 \mathrm{mg} / \mathrm{kg}$ b.wt.) every other day for six weeks caused significant increase and decrease in serum in IL-6 and IgG concentrations respectively, and insignificant increase in serum IgM concentration, with respect to the control value of each parameter measured. Repeated po administration of vitamin C $(200 \mathrm{mg} / \mathrm{kg}$ b.wt.) alone for a similar treatment period induced significant increases in serum levels of IL-6 and IgM and a slight decrease of serum IgG. However, when it was administered 30 minutes after each AP administration, it reduced slightly the increasing effect of AP on IL-6 and reversed and potentiated significantly its actions on IgG and IgM respectively.

Table 2 and figures 4,5 and 6 show that same AP administration induced significant increases in total WBCs count and the percentage of monocytes and lymphocytes above the control values. It is also shown that similar increases in WBCs count, or monocytes and lymphocytes percentage

occurred in rats administered po with vitamin $\mathrm{C}$ alone or 30 minutes following each AP treatment. 
Table 1 : Effects of repeated po administration of Acetamiprid (AP) at the dose level of $1 / 10 \mathrm{LD}_{50}(83.18 \mathrm{mg} / \mathrm{kg}$ b.wt. $)$ every other day for six weeks and that of vitamin $\mathrm{C}$ at po dose of $200 \mathrm{mg} / \mathrm{kg} \mathrm{b}$.wt. alone or after 30 minutes of each AP administration for a similar treatment period on serum IL-6, and the immunoglobulins IgG and IgM

\begin{tabular}{|c|c|c|c|}
\hline \multirow{2}{*}{ Group } & $\begin{array}{c}\text { IL-6 } \\
\text { (pg/ml) }\end{array}$ & $\begin{array}{l}\mathrm{IgG} \\
(\mathrm{g} / \mathrm{l})\end{array}$ & $\begin{array}{l}\operatorname{IgM} \\
(g / 1)\end{array}$ \\
\hline & Mean $\pm \mathrm{SE}^{*}$ & Mean $\pm \mathrm{SE}^{*}$ & Mean $\pm \mathrm{SE}^{*}$ \\
\hline Control & $8.21 \pm 0.117$ & $3.53 \pm 0.092$ & $0.45 \pm 0.019$ \\
\hline Acetamiprid & $16.53 \pm 0.510^{\mathrm{a}^{+}}$ & $2.15 \pm 0.060^{\mathrm{a}^{+}}$ & $0.49 \pm 0.040^{\mathrm{a}-}$ \\
\hline Vitamin C & $16.08 \pm 1.076^{\mathrm{a}^{+}}$ & $3.00 \pm 0.046^{\mathrm{a}^{+}}$ & $0.53 \pm 0.016^{\mathrm{a}^{+}}$ \\
\hline $\begin{array}{c}\text { Acetamiprid } \\
\& \\
\text { Vitamin C }\end{array}$ & $14.01 \pm 0.481^{\mathrm{a}+, \mathrm{b}+}$ & $3.43 \pm 0.070^{\mathrm{a}-\mathrm{b}+}$ & $0.60 \pm 0.033^{\mathrm{a}^{\mathrm{a}, \mathrm{b}+}}$ \\
\hline
\end{tabular}

* Results are expressed as Mean \pm SE of 8 samples

${ }^{a+}$ significant when compared with the control values $(p \leq 0.05)$

${ }^{a-}$ non significant when compared with the control values $(p \leq 0.05)$

${ }^{\mathrm{b}+}$ significant when compared with the acetamiprid treatment values ( $\mathrm{p} \leq 0.05)$ 
Nagi A. Ibrahim. et al..

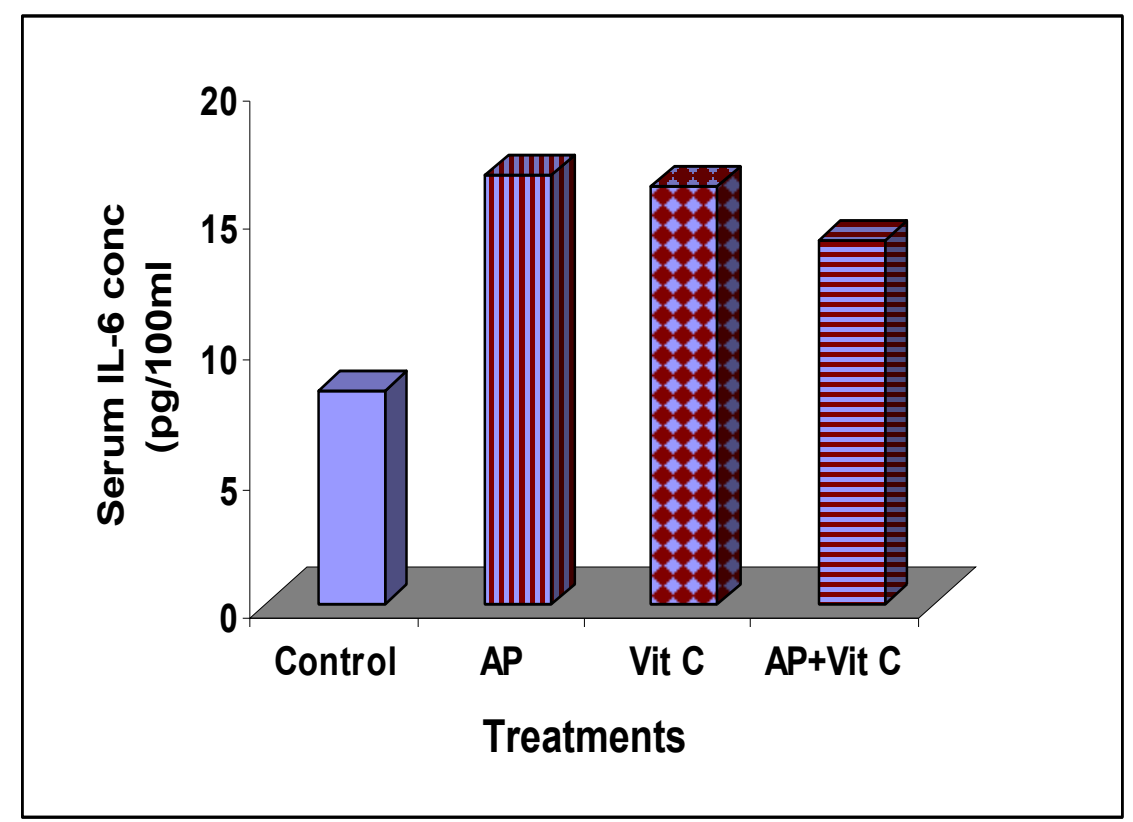

Figure (1) : Changes in interleukin-6

following every other day post oral administration for 6 weeks of AP $\left(1 / 10 \mathrm{LD}_{50}\right)$, Vit C alone $(200 \mathrm{mg} / \mathrm{kg}$ b.wt.) and $\mathrm{AP}+\mathrm{VitC}\left(1 / 10 \mathrm{LD}_{50}+200 \mathrm{mg} / \mathrm{kg}\right.$ b.wt. $)$ into male albino rats. Each value represents the Mean \pm SE of eight animals.

AP: Acetamiprid; Vit C: Vitamin C 


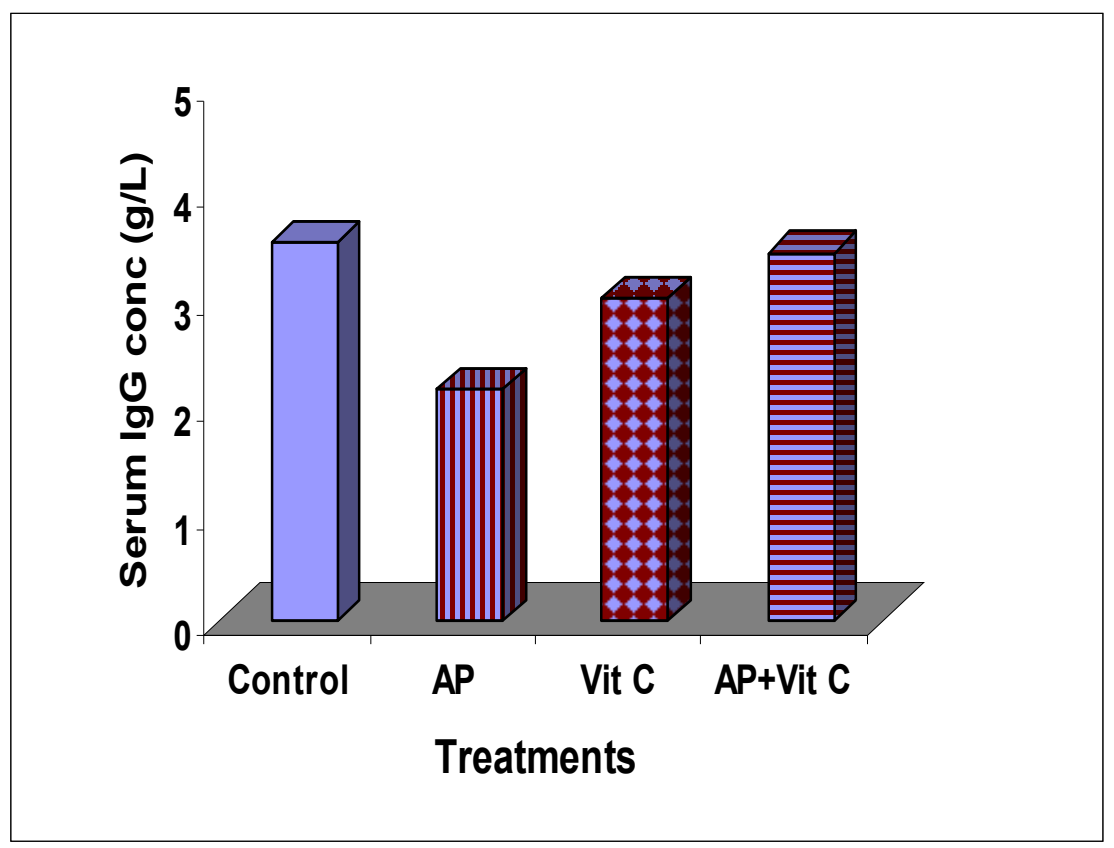

Figure (2): Changes in serum IgG concentration following every other day post oral administration for 6 weeks of AP $\left(1 / 10 \mathrm{LD}_{50} / 100\right.$ g b.wt.), Vit C alone (200ml/kg b.wt.)and AP +VitC (1/10 LD ${ }_{50^{+}}$ $200 \mathrm{mg} / \mathrm{kg}$ b.wt.) ) into male albino rats. Each value represents the Mean \pm SE of eight animals.

AP: Acetamiprid; Vit C: Vitamin C. 
Nagi A. Ibrahim. et al..

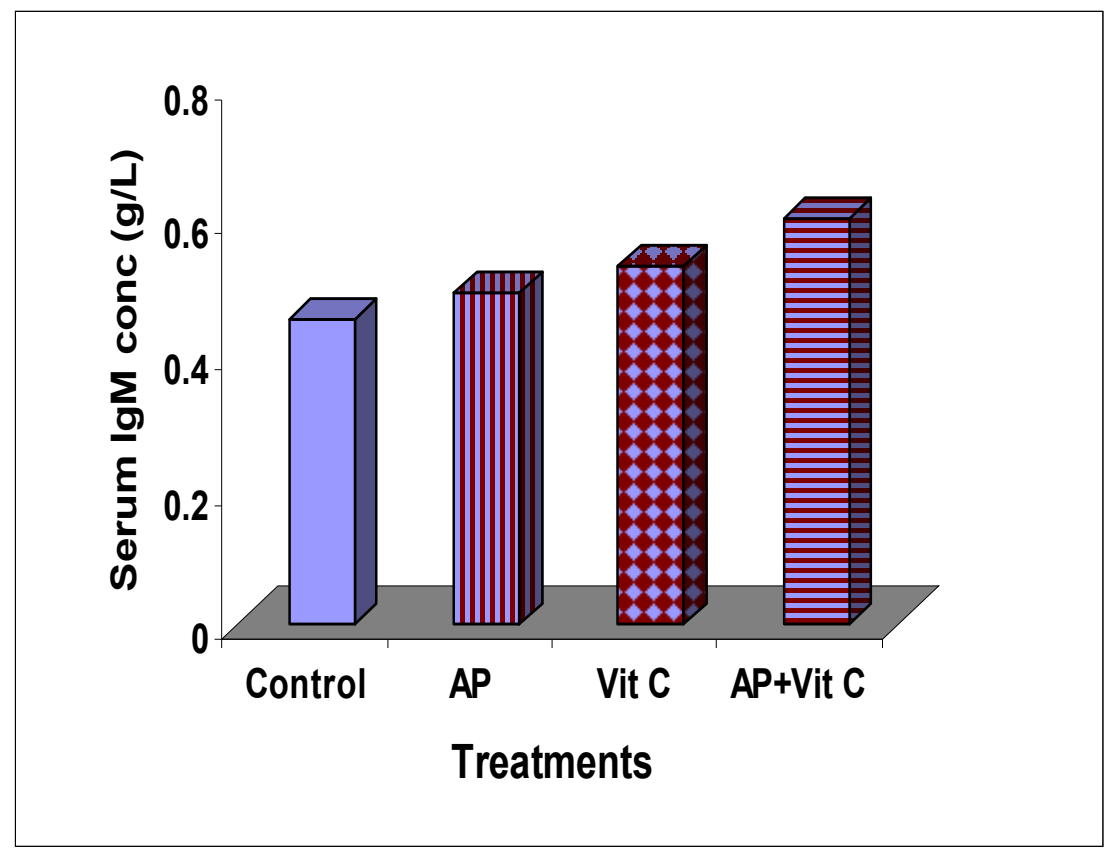

Figure (3): Changes in serum IgM concentration following every other day post oral administration for 6 weeks of AP $\left(1 / 10 \mathrm{LD}_{50}\right.$ $/ \mathrm{kg}$ b.wt.), vitamin C alone (200 mg/kg b.wt.) and AP +Vit C (1/10 $\mathrm{LD}_{50}+200 \mathrm{mg} / \mathrm{kg}$ b.wt.) into male albino rats. Each value represents the Mean \pm SE of eight animals

AP: Acetamiprid; Vit C: Vitamin C. 
Humoral Immun Response To Acetamiprid

\begin{tabular}{|c|c|c|c|}
\hline \multirow{2}{*}{ Group } & $\begin{array}{c}\text { WBCs Count } \\
\left(\mathrm{x} 10^{3} / \mu \mathrm{L}\right)\end{array}$ & $\begin{array}{c}\text { Monocytes } \\
\%\end{array}$ & $\begin{array}{c}\text { Lymphocytes } \\
\%\end{array}$ \\
\cline { 2 - 4 } & Mean $\pm \mathrm{SE}^{*}$ & Mean $\pm \mathrm{SE}^{*}$ & Mean $\pm \mathrm{SE}^{*}$ \\
\hline Control & $5.80 \pm 0.117$ & $7.09 \pm 0.369$ & $38.19 \pm 1.071$ \\
\hline Acetamiprid & $7.19 \pm 0.133^{\mathrm{a}+}$ & $17.39 \pm 0.522^{\mathrm{a}+}$ & $66.06 \pm 0.949^{\mathrm{a}+}$ \\
\hline $\begin{array}{c}\text { Vitamin C } \\
\begin{array}{c}\text { Acetamiprid } \\
\& \\
\text { Vitamin C }\end{array}\end{array}$ & $7.93 \pm 0.124^{\mathrm{a}+}$ & $20.88 \pm 0.792^{\mathrm{a}+}$ & $63.84 \pm 0.832^{\mathrm{a}+}$ \\
\hline
\end{tabular}

Table 2 : Effects of repeated po administration of acetamiprid (AP) at the dose level of $1 / 10 \mathrm{LD}_{50}(83.18 \mathrm{mg} / \mathrm{kg} \mathrm{b}$.wt. $)$ every other day for six weeks and that of vitamin C at po dose of $200 \mathrm{mg} / \mathrm{kg}$ b. wt. alone or after 30 minutes of each AP administration for a similar treatment period on total WBCs count, monocytes and lymphocytes percentages.

* Results are expressed as Mean \pm SE of 8 samples

${ }^{a+}$ significant when compared with the control values $(p \leq 0.05)$

${ }^{\mathrm{b}+}$ significant when compared with the acetamiprid treatment values ( $\mathrm{p} \leq 0.05)$ 
Nagi A. Ibrahim. et al..

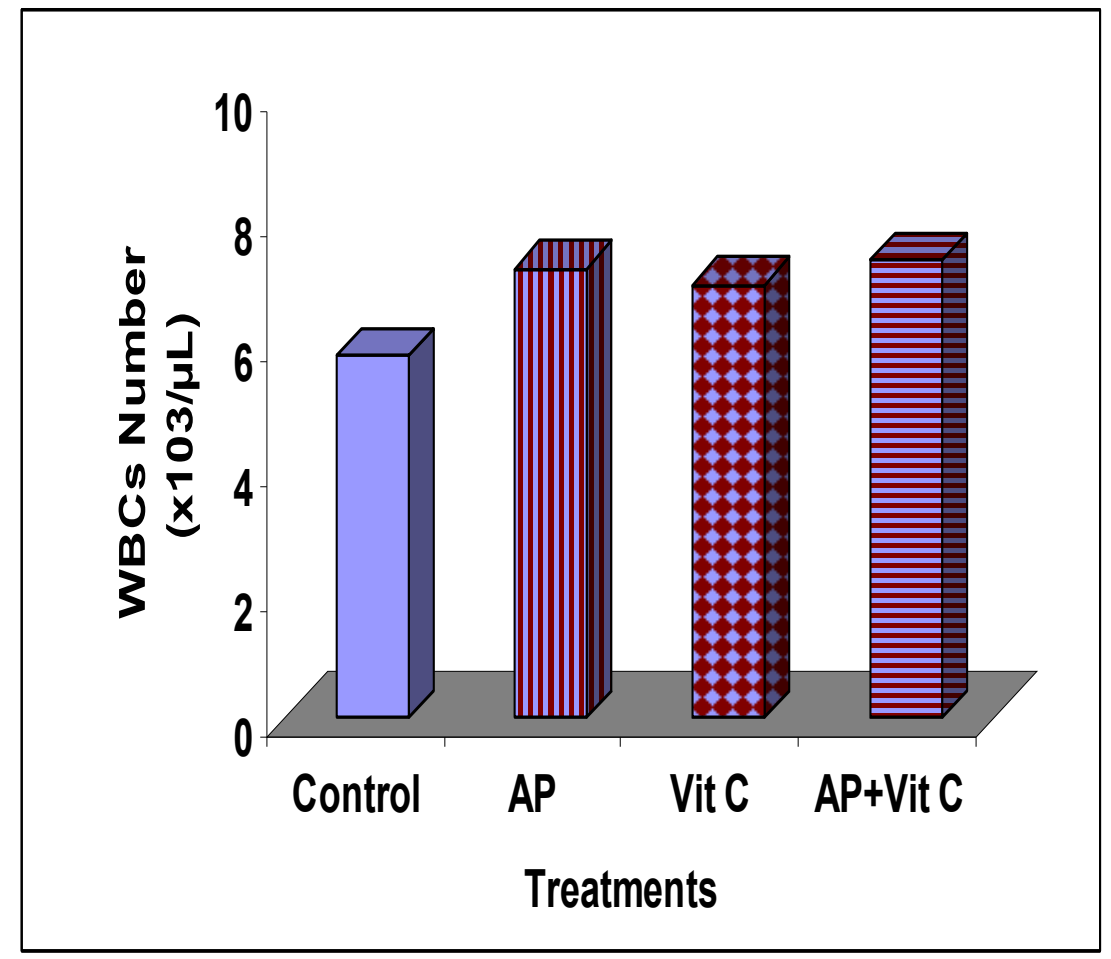

Figure (4): Changes in total WBCs count following every other day post oral administration for 6 weeks of AP (1/10 $\mathrm{LD}_{50} / \mathrm{kg} / \mathrm{b}$.wt.), Vit C alone (200mg/kg b.wt.) and AP + VitC (1/10 $\mathrm{LD}_{50}+200 / \mathrm{mg} / \mathrm{kg}$ b.wt.) into male albino rats .Each value represents the Mean $\pm \mathrm{SE}$ of eight animals.

AP: Acetamiprid; Vit C: Vitamin 


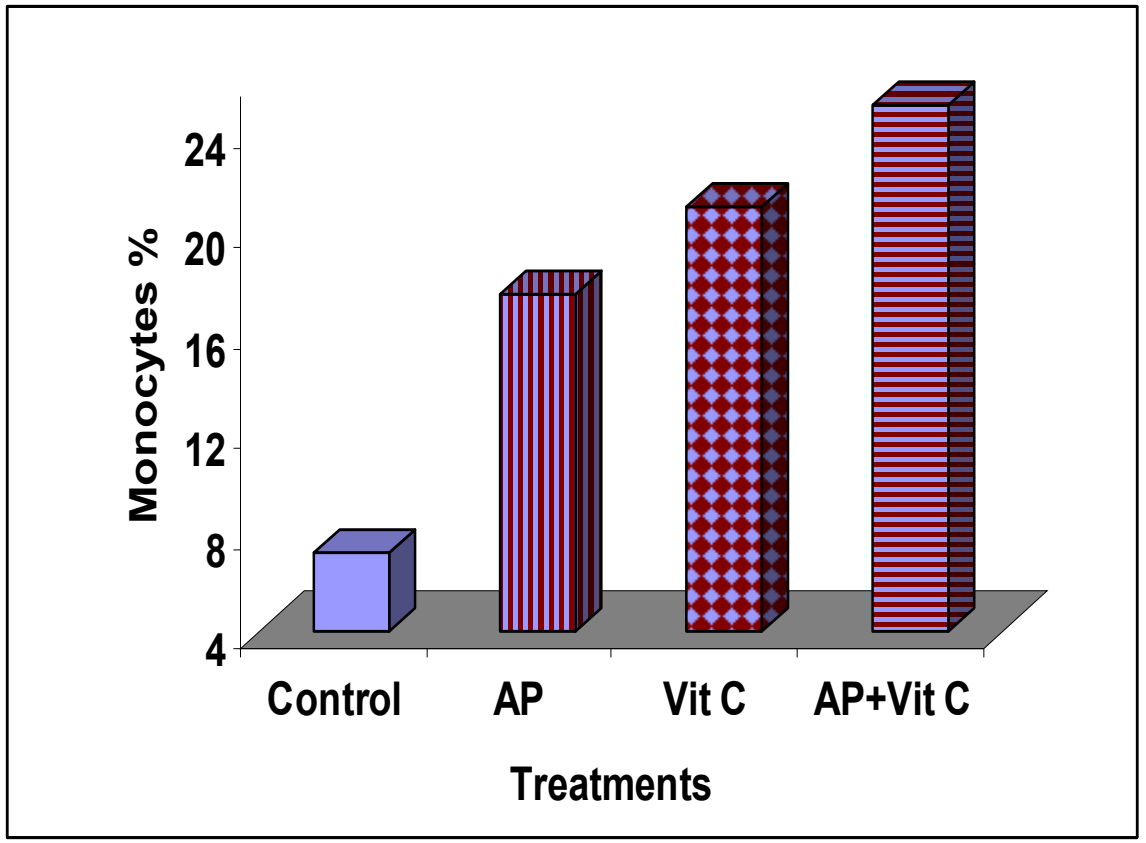

Figure (5): Changes in monocytes percentage following every other day post oral administration for 6 weeks of AP $(1 / 10$ $\mathrm{LD}_{50}$.), Vit C alone $\left(200 \mathrm{mg} / \mathrm{kg}\right.$ b.wt.) and AP + VitC $\left(/ 10 \mathrm{LD}_{50}+200\right.$ $\mathrm{mg} / 1 \mathrm{~kg}$ b.wt.) into male albino rats. Each value represents the Mean \pm SE of eight animals.

AP: Acetamiprid; Vit C: Vitamin C. 
Nagi A. Ibrahim. et al..

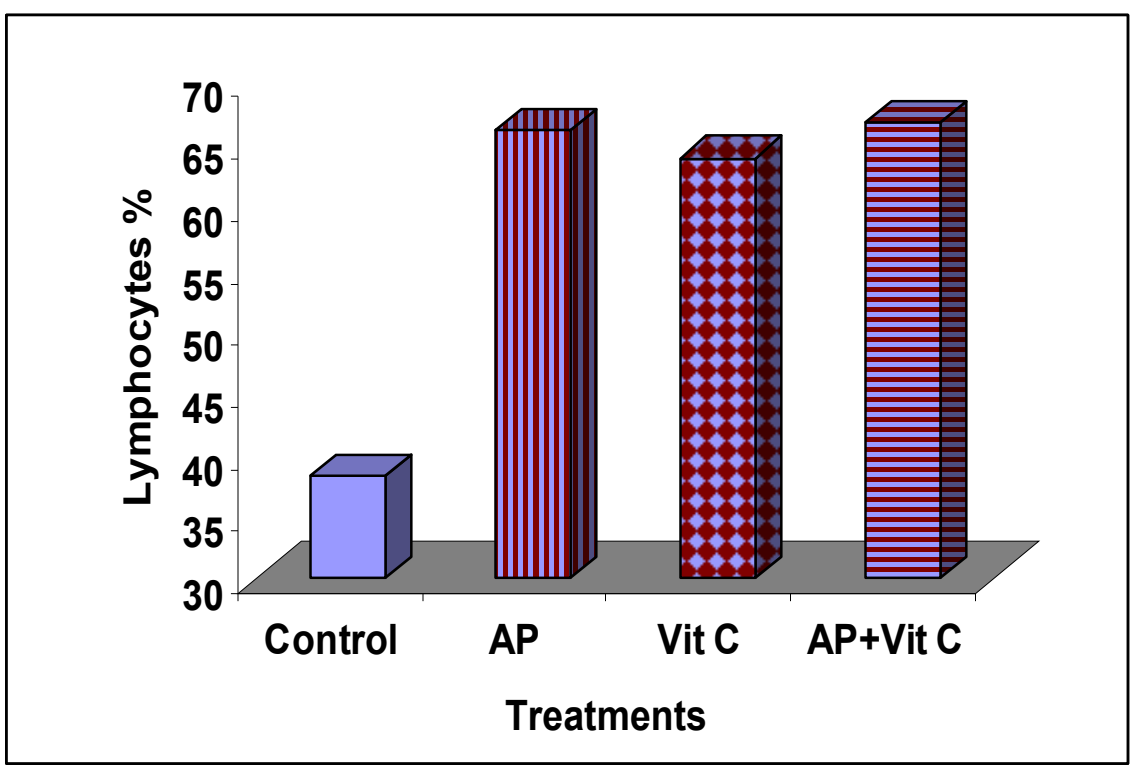

Figure (6): Changes in lymphocytes percentage following every other day post oral administration for 6 weeks of AP $(1 / 10$ $\mathrm{LD}_{50}$.), Vit $\mathrm{C}$ alone (200 $\mathrm{mg} / \mathrm{kg}$ b.wt.) and $\mathrm{AP}+\mathrm{VitC}\left(1 / 10 \mathrm{LD}_{50}+200 \mathrm{mg} / 1 \mathrm{~kg}\right.$ b.wt. $)$ into male albino rats. Each value represents the Mean \pm SE of eight animals. AP: Acetamiprid; Vit C: Vitamin C.

\section{DISCUSSION}

Neonicotinoids, the newest major class of insecticides, have outstanding potency and systemic action for crop protection against

piercing - sucking pests, and also have high effectiveness for animals health care ${ }^{(1,9,10,33,34)}$. 
These systemic insecticides are agonists of nicotinic acetylcholine receptors (nAChR). However, they have significant toxicity to mammals because of their stronger affinity for insects nAChR than for mammals ${ }^{(9,10)}$.

In addition to the function of IL-6 as a growth and differentiation factor in the haematopoietic and immune system, IL-6 has been described to stimulate proliferation of human leukaemia and lymphoma cells ${ }^{(35)}$.

Since monocytes, $\mathrm{T}$ and $\mathrm{B}$ lymphocytes are examples of many diverse cell types produce IL-6 in response to various stimuli ${ }^{(36)}$, the present elevation in serum IL-6 concomitant increases in monocytes, Tand B lymphocytes could be speculated to be possibly controled via a positive autocrine feedback loop.

The primary function of WBCs is defense against foreign bodies, which is achieved by leukocytosis and antibody production. Data presented in the current study revealed a higher WBCs number in rats treated with AP insecticide. These results agree with those found in rats treated with imidacloprid ${ }^{(\mathbf{2 1 , 3 7 )}}$ and in mice treated with $\mathrm{AP}^{\mathbf{( 3 8 , 3 9 )}}$. This increase has been previously suggested to be related to an increase in lymphocytes number ${ }^{(21)}$. This suggestion is supported by the present increase in monocytes and lymphocytes percentage recorded concomitantly with the increase WBCs number.

The present AP toxicity was observed to induce a significant decrease in serum IgG level concomitant with insignificant increase in IgM level. This observation disagrees with that obtained by Mohany et al $^{(21)}$, who reported a significant increase in serum level $\operatorname{IgG}$ without any significant change in $\operatorname{IgM}$ in rats treated with imidacloprid, they attributed the increase in immunoglobulin to the formation of anti-imidacloprid antibodies.

In contrast with the present finding, Mondal et al., ${ }^{(\mathbf{1 2})}$ reported a significant decrease in mean values of total WBCs number and relative lymphocyte count in female Wister rats treated orally with AP. They suggested that their observation to be due to a direct cytotoxic effect on leukocytes as was also suggested in gentamicin toxicity in guinea pigs ${ }^{(40)}$. 
Nagi A. Ibrahim. et al..

In the present study, po administration of vitamin $\mathrm{C}$ alone caused significant elevations of serum IL-6 and IgM levels ; WBCs count, monocytes and lymphocytes percentages, and a decrease of IgG level . Interestingly, co - administration of vitamin $\mathrm{C}$ with acetamiprid was unable to reverse but instead enhanced the elevation of IgM, WBCs count, monocytes and lymphocytes percentages caused by the administration of acetamiprid alone . On the contrary, vitamin $\mathrm{C}$ was found to reduce significantly the changes in IL -6 and IgG recorded following the administration of acetamiprid alone . These findings agree with the notion that antioxidants may show protective effects on some biochemical indices but not on some parameters $^{(41,42)}$. However, several studies have indicated the ameliorative effect of vitamin $\mathrm{C}$ supplementation against toxicity of several insecticides including, hematological and / or biochemical toxicity of chlorpyrifos ${ }^{(43)}$; deltamethrin ${ }^{28}$; malathion ${ }^{(44)}$; renal toxicity of lambda cyhalothrin ${ }^{(27)}$; fenvalerate ${ }^{45}$ and hepatotoxicity of fenvalerate $^{(45,46)}$; propanil ${ }^{(42)}$.

Although the underlying mechanism through which vitamin $\mathrm{C}$ functions against deleterious effects of chemicals is still unclear, it has been reported that its primary role is to neutralizes free radicals, since ascorbic acid is water soluble, it can work both inside and outside the cells to combat free radical damage . the free radicals will seek out an electron to regain their stability, vitamin $\mathrm{C}$ is an excellent source of electrons; therefore, it can donate electrons to free radicals such as hydroxyl and superoxide radicals and quench their reactivity (47).

Overall, the present findings demonstrate that the exposure of animals to acetamiprid insecticide is capable of inducing marked alterations in some humoral immune parameters which were selectively ameliorated by co - administration of vitamin $\mathrm{C}$. 
Humoral Immun Response To Acetamiprid

\section{REFERENCES}

1-Casida, J.E. ,Quistad, G.B. (1998): Golden age of insecticide research : past, present, or future ? Annu . Rev. Etomol. 43:1-16.

2-Blakley, B.; Brousseau, p.; Fournier, M. and Voccia, I. (1999) : Immunotoxicity of pesticides : a review. Toxical. Ind. Health 15: $119-132$.

3-Ray, D.E. and Forshaw, P.J. (2000) : Pyrethroid insecticides : poisoninig syndromes, synergies, and therapy. J. Toxicol. Clin. Toxicol ., 30(2) : 95 - 101.

4-Satoh, T. and Hosokawa, M. (2000) : Organphosphates and their impact on the global environment. Neurotoxicol, $21: 223-$ 227.

5-Ibrahim, N. A. ; Mansour, M. A. and Al Muslemani, F. A. (2002) : changes in lipid profiles of serum and some organ tissues affected by intoxication with two different insecticides. Bull. Egypt. Soc. Physiol. Sci. 22(2): 276 - 308.

6-Ibrahim, N. A. ; Mansour, M. A. and Al Muslemani, F. A. (2004) : Haematotoxicity of an organophosphate and a synthetic pyrethroid insecticides in a mammalian animal. Proc. Int. Conf. Biol.Sci.3 (1) : 1108 - 1126.

7-Chiyozo, T. (2008) : The history of insecticides and the transition of their production. Jpn J. Toxicol. $21: 123-131$.

8-Kovganko, N.V. ; Kashkan, Z. N. (2004) : Advances in the synthesis of neonicotinoids. Russian J. Org. Chem. 40 : 1709 -1726 . 
9-Tomizawa, M. and Casida, J. E. (2005) : Neonicotinoids insecticide toxicology : mechanisms of selective action. Ann. Rev. Pharmacol. Toxicol. $45: 247-268$.

10-Tomizawa, M. and Casida, J. E. (2003) : Selective toxicity of neonicotinoids attributable to specificity of insect and mammalian nicotinic receptors. Annu. Rev. Entomol. 48 : $339-364$.

11-Ambrose, M. L. (2003) : Characterization of the insecticidal properties of acetamiprid under field and laboratory conditions. A thesis submitted to the Graduate Faculty of North Carolina State University. Raleigh US.

12-Mondal, S. ; Ghosh, R. C. ; Mate M. S. and Karmakar D.B. (2009): Effects of acetamiprid on Immune System in Female Wistar Rats proc. Zool. Soc. 62(2): 109-117.

13-Mondal, S. ; Ghosh, R. C. and Mukhopadhyaya S. K. (2011): Studies on the electrolytes and microelements in Wistar Rats following multiple exposure to Acetamiprid. Toxicol. Indust. Health. 1-6.

14-Dean, J. H. and Murray, M. J. (1991): Toxic Responses of the Immune System. In: Amdur, M.O., Doull, J., Klaassen, C.D. (Eds.), Casarett and Doull's Toxicology, The Basic Science of Poisons, 4th edition, Pergamon Press, Inc., New York, pp. 282-333.

15- Loveless, S. E. and Ladics, G. S. (1995): Review and recent advances in immunotoxicology. In: Middleton, E., Jr., Reed, C.E., Ellis, E.F., Adkinson, N.F., Jr., Yunginger, J.W., Busse, W.W. (Eds.), Allergy: Principles and Practice, 4th edition, Mosby, St. Louis, MO, pp. 1 
16- Cha, S. W. ; Gu, H. K. ; Lee, K. P. ; Lee, M. H. ; Han, S. S. and Jeong, T. C. (2000): Immunotxicity of ethyl carbamate in female BALB/c mice: role of esterase and cytochrome P450. Toxicol. Lett. 115: 173-181

17-Kumar, R.; Singhal, L. K.;Singh, B. P. and Chauhan, R. S. (2002): Effect of butachlor on cell-mediated immunity in chicken. J. Immunol. Immunopathol. 4(1): 84-87.

18- Prater, M. R. (2003): Immunotoxicity of dermal permethrin and cis-urocanic acid: effects of chemical mixtures in environmental health. Ph. D. thesis submitted to Virginia Polytechnic Institute and State University. Virginia.

19-Galloway, T., Handy, R. (2003): Immunotoxicity of organophosphorus pesticide. Ecotoxicol. 12: 325-363.

20- Gatne, M. M.; Ramesh, Bhoir, P. S., Deore, M. D. (2006) Immunotoxicity studies of imidacloprid in rats. Toxicol. Int. 13(2): 89-92.

21- Mohany, M. ; Badr, G. ; Refaat, I. and El-Fekis, M. (2011): Immunological and histological effects of exposure to imidacloprid insecticide in male albino rats. Afr. J. Pharm. Pharmacol., Vol. 5(18), pp. 2106-2114.

22 - Grajeda-Cota, P. , Ramirez-Mares, M.V., Mejia, E,G. (2004) : Vitamin $\mathrm{C}$ protects against in vitro cytotoxicity of cypermethrin in rat hepatocytes. Toxicol. In Vitro , $18: 13-$ 19 .

23 - Kalender, S. , Kalender, Y., Ogutcu, A. , Uzunhisarcikili, M. , Durak, D. , Acikgoz, F. (2004) : Endosulfan-induced cardiotoxicity and free radical metabolism in rats : The protective effect of vitamin E . Toxicol., 202: $227-235$. 
24 -Benerjee, B.D. , Seth, V. , Ahmed, R.S. (2001) : Pesticideinduced oxidative stress : Perspectives and trends . Rev. Environ. Health, $16: 1-40$.

25- Iqbal, K. , Khan, A. , Khattak, M. (2004) : Biological significance of ascorbic acid (Vitamin C) in human health a review. Pak. J. Nutr. $3: 5-13$.

26- Reed, L. H. and Meuench, H. (1938): A simple method of estimating fifty percent point. Am. J. Hyg. 37: 493.

27 - Fetoui, H. , Maki, M. , Garui, E. , Zeghal, N. (2010) : Toxic effect of lambda-cyhalothrin, a synthetic insecticide, on the rat kidney Involvement of oxidative role of ascorbic acid. Exp .Toxicol. Pathol.

$62: 593-599$,

28 - Mongi, S. , Mahfoud, M. , Amel, B. , Kamel, J. , Abdefattah, E. (2011) : Protective effect of vitamin $C$ against haematological and biochemical toxicity induced by deltamethrin in male Wister rats . Ecotoxicol. Environ. Safety . 74 (6) : $1765-1769$.

29- Thomas, L. (1998): Immunoglobulins (Ig). In : Clinical laboratory Diagnostics, pp 667-678 Tomas, L . Ed. , THbooks Frankfurt / Main.

30 - Harris, N. J. ; Jou, M. ; Ranovics, D. W. ; Evoto, G. D. and Wilkinson, M. (2005): Performance evaluation of the ADVIA 2120 Hematological analyzer : An international Multicenter Clinical Trial,University of Florida/Shands Hospital Core Laboratory, Gainesville, Florida, USA.

31- Hill, A. B. (1971) : Principles of medical statistics $9^{\text {Th }}$ ed. Oxford Univ. Press. 
32- Kirkwood, B.R. (1989): Essentials of Medical Statistics. $3^{\text {rd }}$ ed Blackwell Scientific Publication. P 151.

33- Yamamoto, I. and Casida, J. E. (1999) : Neonicotinoide insecticides and the nicotinic acetylcholine receptors. Tokyo; Springer Verlag.

34- Phua, D. H. ; Lin, C. C. ; Wu, M. L. ; Deng, J. F. ; yang, C. C. (2009) : Neonicotinoide insecticides : an emerging cause of acute pesticide poisoning. Clin. Toxicol. (Phila), 47 : 336341

35- Heinrich, P. C. ; Castell, J. V. ; Andus, T. (1990) : Interleukin-6 and the acute phase response. Biochem. J. $265: 621-436$.

36- Barton, B.E. (1996): The biological effects of interleukin 6. Med. Res. Rev. 16 (1): 87-109.

37- Ammar, M. ; Rabeih, K. ; Abou El-Khear, A. and Nema, M. (2003): Hematological studies of some pesticides on albino rats, Rattus norvigecus albinus. Alex J. Pharmaceut. Sci. Egy., 17: 21-27.

38- Deifalla, H. A. and El- Shahawy, F. I. (1998) : Toxicity and Biochemical effects of lead, Cadmium, Acetamiprid and their mixture on male mice .J. pest Cont. Sci. 6 (1) : 49-64.

39- El- Shahawy, F. I. ; Deifalla, H. A. ; Mostafa, S. M. (1999) : Hematological, physiological responses and hepatic function in the male mice exposed to acetamiprid, lead, cadmium, and their mixture. Alex . J. pharm. Sci. 13(2) : 125-129.

40- Gupta, R. P. ; Verma, P. C. (1998) : Effect of gentamicin administration on certain clinico-pathological and mineral studies in guinea pigs. Indian J. Vet. Pathol. 22 (2) : 123126. 
Nagi A. Ibrahim. et al..

41- Kalender, S. , Uzun, F.G. , Durak, D. , Demir, D. , Kalender, Y. (2010) : Malathion - induced hepatotoxicity in rats : The effect of vitamins Cand E .Food Chem. Toxicol. 48 : 633 638 .

42- Otuechere, C. , Abarikwu, S. , Rufai, M. Ohiozje, A. Martins,

E. Farombi, E. (2012) : Protective effect of vitamin C against propanil - induced hepatotoxicity in Wister rats . Asian Pacific J, tropical Disease. S212-S217.

43- Ambali, S., Akanbi, D. , Igbokwe, N, , Shittu, M. Kawu, M. , Ayo, J. (2007) : Evaluation of subchronic chlorpyrifos poisoning on hematological and serum biochemical changes in mice and protective effect of vitamin C. J. Toxicol. Sci. $32(2): 111-120$.

44 - Ismail, S.M. (2013) : Protective of vitamin C against biochemical toxicity induced by malathion pesticide in male albino rat . J. Evolut. Biol. Res., 5(1) : $1-5$.

45- Hussein, H. K. , Elnaggar, M.H. , Al-Dailamy, J.M. (2012) : Protective role of vitamin $\mathrm{C}$ against hepatorenal toxicity of fenvalerate in male rats . Glo. Res. J. Environ. Sci. Toxicol, $1(4): 60-65$.

46 - $\quad$ Fetoui, H., Garui, E., Zeghal, E, (2009) : Lambdacyhalothrin - induced biochemical and histopathological changes in the liver of rats : ameliorative effect of ascorbic acid . Exp.Toxicol. Pathol. $61: 189-196$.

47 - El-Gendy, K.S. , Aly, N.M. , Mahmoud, F.H. , Kenawy, K. , El-Sebae, A.K. (2010) : The role of vitamin $C$ as antioxidant in protection of oxidative stress induced by imidacloprid . Food Chem. Toxicol.,48 : $215-221$. 
Humoral Immun Response To Acetamiprid 